\title{
Finance on Trial
}

\section{Rules and Justifications in the Libor Case}

\begin{abstract}
In the context of the recent financial meltdown, the financial industry has frequently been accused of being indifferent to the irregular practices of its members or even to be criminogenic. But how do actors of the financial industry respond to such accusations and defend themselves? How do they justify their actions when facing legal charges as well as public blame? This article elucidates these questions through a rare ethnographic case: the first criminal trial of a trader involved in the manipulation of Libor, which took place in London in 2015. Tied to at least $\$ 300$ trillion contracts, Libor is a benchmark that plays a key role in the financial industry. The paper offers a sociological framework to capture the justifications of financial wrongdoings, arguing that they are structured around three elements: (a) a conception of rules; (b) a narrative; (c) a form of responsibility. I distinguish three justifications: the one of the maker, of the interpreter and of the user. I finally discuss how these justifications contribute to the general tolerance towards white-collar crime.
\end{abstract}

Keywords: Finance; Trials; Justifications; Rules; Libor; Illegality of rights; Whitecollar crime.

H OW D O PEOPLE EX P L A N their actions? How can we understand the reasons they provide when facing accusations of wrongdoing or misconduct? In such situations, individuals adopt a certain number of positions that are not random but respond to social logic. As C. Wright Mills reminds us, the "different reasons men give for their actions are not themselves without reasons" [Mills i 940: 904]. Indeed, for more than three decades, sociology has dedicated considerable effort to this process of justification [Boltanski and Thévenot I 999; 2006; Tilly 2006]. It leads to approach the social world as a continuous trial [Boltanski and Claverie 2007] in which individuals are required to bring proof to their argumentation and to provide some form of generality to their particular situation. In order to be considered as valid, justifications require the use of de-individualized and general

Thomas Angeletti, Max-Planck-Institut für Gesellschaftsforschung, Köln [ta@ mpifg.de].

European Fournal of Sociology, 58, I (2017), pp. I I3-I4I-0003-9756/17/0000-900\$07.50per art + \$o.10 per page (C)European Fournal of Sociology 2017. doi: 10.1017/So003975617000030 
arguments, which are attached to the larger principles of legitimacy governing modern societies.

Since the beginning of the financial crisis in 2007-2008, the legitimacy of financial capitalism has come under regular criticism [Münnich 20I5]. From the Occupy movement to a succession of scandals, it seems that not a day flew by without new revelations of misconduct relating to the banking and financial industry. Such times of scandals can result in a rise in the reflexivity and critical capacities of social actors [Thompson 2000; Adut 2005; Boltanski et al. 2007; Boltanski 20I2]. Indeed, the subprime crisis, the cases of insidertrading such as Jérôme Kerviel and Société Générale, the recent Panama Papers as well as many other affairs led to moral condemnations of the financial industry. The financial industry has been frequently accused of being indifferent to the practices of its members or even to be criminogenic. From the use of derivatives to the unconsciousness of the subprime crisis, from high profit-seeking and the rise of wages and bonuses [Godechot 20I7] to the emphasis on maximizing shareholder value [Lazonick and O'Sullivan 2000; Dobbin and Zorn 2005], political elites as well as citizens have regularly denounced the excesses of finance. To a certain extent, it has even become mundane to critique finance and to engage in this massive blame game [Tilly 2008, 2010]. But how do members of the financial industry actually respond to such accusations and attempt to defend themselves? How do they try to justify their actions when facing legal charges as well as public blame?

This paper tackles these questions by building on a rare case: the trial of the first financial trader judged as part of the Libor scandal. Libor (London Interbank Offered Rate) is a London-based rate dedicated to evaluating lending possibilities between banks, and is generally considered a good indicator of the general situation of the financial markets. Libor is a reference for countless financial and physical products and contracts: when Libor moves, the value of the related products also moves. The fairness of Libor is therefore crucially important with regard to the stability of the banking system. In 2012, the British and American authorities announced that they were conducting criminal investigations into the manipulation of Libor. Several banks, including Barclays, Citigroup and UBs were accused of having rigged the rate and agreed to pay significant fines. In December 20I2, the British authorities arrested a first trader and charged him with 8 counts of "conspiracy to defraud". I conducted an ethnographic study on his ro-week trial which took place in London in 20I 5. During the court hearings, the question of what were legitimate 
practices related to Libor-and beyond in the financial industry-was strongly disputed and highlighted a number of different types of justifications.

Trials are especially adapted to the purpose of this paper: they are situations in which the constraints of justification reach an especially high level, to the extent that the arguments relied on need to be publicly defendable. By allowing me to observe these disputes, this trial provided a unique occasion to identify how actors in the financial industry tried to justify their actions in the post-crisis context. Research on the trials of elites or individuals with high-status positions have been very common in history, and even more so in relation to war crimes. The r 96 I Eichmann trial, covered by Hannah Arendt remains a famous example [Arendt I963]. But studies of trials against economic elites are uncommon if not absent in the sociological literature. Moreover, if quantitative studies on white-collar convictions following Sutherland's seminal work [Sutherland I983] are already difficult to find [e.g., Brickey 2006; Garrett 2014], that is even more the case for qualitative studies concerned with courtroom disputes. ${ }^{\mathrm{I}}$ Furthermore, while several pieces of research have investigated the causes and characteristics of the financial crisis [for instance Lounsbury and Hirsch 20I0; MacKenzie 20II], sociological investigations of the financial industry are also concerned with the place of illegality [Beckert and Wehinger 2013; Fligstein and Roehrkasse 20I6], and more broadly about the justifications of financial capitalism. While markets [Lounsbury and Hirsch 2010] and elites [Morgan, Hirsch and Quack 20I5] have been figuratively considered to be on trial, there is much to be learnt from actual trials related to market and elites.

To sum up, this study is an ethnographic investigation of justifications in a specific historical, geographical and sociological context. Historically, the case took place during a major financial crisis, almost a decade after its eruption and while its consequences were still being widely discussed. Geographically, the case was judged in London, one of the world's largest financial centers, and Libor was strongly integrated in the British context. Sociologically, the case is related to practices in the financial industry and to the manipulation of a rate, which should be seen as a white-collar crime. These specificities should be kept in mind when considering how the findings could be extended and generalized [Small 2009].

${ }^{\mathrm{I}}$ Juvenile justice is one of the rare domains in which such studies can be found in

the wake of Cicourel's research [Cicourel I995]. 
The paper is structured as follows. First, I describe how Libor was supposed to function. I set out the main details of the scandal concerning its manipulation and my investigation of the trial. Second, I present the framework used to examine this case and argue that rules played a major role in differentiating the justifications used. I distinguish between three justifying positions which I call respectively: the maker, the interpreter, the user. This allows me, in the third section, to explain the justifications deployed during the first trial of a trader charged with manipulation of Libor.

\section{The Libor scandal: from the manipulation of a rate to its trial}

With the financialization of capitalism [Krippner 20I I], the financial sector has become prominent in recent decades, and has also been strongly identified as a cause of the resurgence in inequalities. By way of example, finance was the primary source of wealth for only $4.6 \%$ of the super-rich listed in the Forbes 400 in 1982 . However, by 2012 , finance had become the dominant sector, accounting for $20.7 \%$ of the list [Korom, Lutter and Beckert 20I5]. Important research has shown that the increasing inequalities of the past four decades and the emergence of the "one percent" [Keister 20I4]—or even the 0.I\%—can be partly explained by the rise of the financial sector, especially in the United States [Philippon and Reshef 2012; Volscho and Kelley 2012], in France [Godechot 20I2] and in the United Kingdom [Bell and Van Reenen 2013]. Finally, since 2007 and the beginning of the so-called financial crisis, the financial industry has been publicly criticized and denounced as a major cause of the global crisis, especially by the Occupy Movement. This historical situation offers an opportunity to examine finance justifications and their implications.

The empirical case on which this paper is based is the Libor scandal. In the following sections, I successively describe Libor and set out the main points of the scandal surrounding its manipulation. I then describe the first trial of a trader judged in relation to this scandal. Finally, I present the data and methodology used in this paper.

\section{The context: what is Libor?}

Libor is a financial benchmark that, along with ratings, is one of the most recent developments that support the financialization of capitalism 
[Krippner 20I I; Van der Zwan 20I4], by providing better information on the situation of the market [Carruthers 20 I5; Bryan and Rafferty 2016]. More precisely, Libor is an interbank rate used by banks to evaluate the borrowing possibilities that exist between banks. After a first attempt at the Chicago Mercantile Exchange in I98I [MacKenzie 2009: 8I], Libor was created in the mid-I980s by the British Bankers' Association (BBA), a trade association which represents the interests of more than 200 domestic and international banks in Britain. It was set up in the broader context of the deregulation of the financial markets, marked especially by the "big bang" reform promoted by the Thatcher administration. ${ }^{2}$ At the time of the scandal, the rate was calculated on a daily basis in London for I 5 different maturities (from one day to one year), and for ro different currencies: euros, dollars, pounds, yen, etc. ${ }^{3}$ I 50 different Libors were calculated each day: it may therefore be more correct to talk about Libors rather than Libor. An important aspect of Libor was that it was not based on transactions that had already occurred: it was the rate that the banks anticipated would be used to borrow money. Most importantly, the total value of contracts and products linked to Libor was estimated to be $\$ 300$ trillion [Wheatley 2012]. This colossal sum includes derivative products, such as options and especially swaps, but also products dedicated to households such as mortgages or student loans. The BBA even qualified and promoted Libor in 2009 as the "world's most important number" [BBA 2009]. But how did Libor work? A panel representing a number of banks (usually between 8 and I6) selected by the BBA was asked to answer a relatively simple and standardized question for all tenors and currencies: ${ }^{4}$

"At what rate could you borrow funds, were you to do so, by asking for and then accepting interbank offers in a reasonable market size just prior to I I a.m.?”

2 An investigation is currently underway to learn and explain (a) why Libor was allocated to the BBA, and (b) why it was calculated in this way. The usual explanation relies on the increase in the number of financial transactions, which is supposed to have logically led to the emergence of this interbank rate-a reference rate that every actor could turn to. Although I do not completely discard this common explanation, it clearly draws on technological or economic determinism. To properly and sociologically explain the creation of this rate, I need to turn to the different forms of mobilization and propositions that were formulated, at the turn of the I980s, as well as the different technical possibilities considered at that time. For recent developments on alternatives to Libor, see [Tabb and Grundfest 20I3].

3 The description of the functioning of Libor and of the organization of its submission refers to the situation that existed at the time of the manipulation, and not that after the reform that followed.

4 The definition of Libor was published on the website of the British Bankers' Association and is still available for consultation even though the administration of Libor was withdrawn from the BBA in 2013. The definition of Libor and information on its administration by the вBA are available at: http://www. bbatrent.com/explained/definitions. 
To participate in these panels, the banks needed to make actual transactions in the currency under consideration. Being part of the panels was very important for the banks: first, because they were in a position to influence Libor and, second, because the banks selected were considered legitimate to pronounce on the situation of the interbank market. Banks were required to answer that question at I I a.m. and send their responses to the institution in charge of calculating the final rate, i.e., Thompson-Reuters. As previously described, the submission of Libor rates by each bank involved a subjective appreciation of the current economic situation. Each rate was based not on past transactions but resulted from the evaluation by an individualthe submitter-of the situation of his bank, of a specific "market", of the economy in general, and the connection between these different factors. In practice, different individuals, with one or more deputies, were designated as submitters of Libor in each bank present in the panels. It was expected that these submitters would "take the pulse of the market", as was stated several times during the trial, by talking to colleagues, such as traders and brokers, by feeling the activity in the trading room, and by looking at the publications and announcements of national and international institutions. On the basis of this information, the submitter inferred the rate at which his bank would be able to borrow funds from the other banks. He then transmitted that rate to Thompson-Reuters, via a dedicated website. Once the 16 rates of each of the panel banks were received by Thompson-Reuters, they were ranked: the top and bottom quartiles were ignored, and the mean of the 8 remaining rates was calculated, in order to produce Libor of the day, for the currency and time period under consideration. Shortly afterwards, the daily rates were disseminated "daily on more than 300,000 screens around the world", according to the BBA [BBA 2008].

As one submitter testified during the trial, the role of a submitter was not a position per se, and represented rather a minor operation: the time for "physically doing the submissions would be very small, io to 5 minutes". At the time, this responsibility was usually conferred on individuals who were seen as the most likely to know the situation of a specific market: the traders. In fact, the submitters were very often traders, sometimes even traders with positions in the currency under consideration and even with positions linked to Libor. In that regard, the submitters personified, in an almost caricatured manner, the type of conflicts of interest involved in the Libor scandalconflicts of interest that are nothing but new in the financial industry [Swedberg 2005]. 
If Libor has been seen-and promoted-as a device designed to reduce uncertainty in financial markets by coordinating the actions of many participants, it can also be seen as a device that introduces another uncertainty by basing its calculation on anticipated transactions. By tasking one individual in each bank with answering the above question, based on the gathering of considerable information and the related inferences in order to produce his own fictional expectations [Beckert 20I6] of the interbank market, the calculation method did indeed place great responsibility on the submitter. The objectivity of the rate [Porter I995; Daston and Galison 2007], if not its facticity [MacKenzie 2007; 2009], was based on the subjectivity of the submitters. Once all these calculations were made, the final rate was supposed to represent the average situation of the banks, i.e., their lending capacities. However, another dimension was also important: at that time, the rates submitted by each bank were published on a daily basis. Everyone could know what Barclays, Société Générale, or UBs submitted for a specific currency and maturity. And precisely these rates could have formed the basis for inferences by other financial actors. What was at stake here was not the average situation in the interbank market, but the specific situation of a given bank. The rate submitted could be seen as a sign of a bank's situation: was it in a position to lend money without difficulty? During the credit crisis, some banks could submit rates that were lower than expected in order to protect their reputation [for Barclays, see Ashton and Christophers 20 I 5].

Following journalistic reports in 2008 by the Wall Street Fournal of irregular submissions of Libor [Mollenkamp 2008], the criminal investigations on the manipulation of Libor debuted in 2012, first in the United States and then in the United Kingdom. On the corporate side-and without even considering here brokerage firms -9 financial institutions have paid more than $\$ 9$ billion in fines to the American, British and European authorities, and the investigation is still open. On the individual side, several brokers, traders and submitters of Libor have been charged and even judged since 20 I 5. At the moment, 24 persons have been charged: 5 are awaiting trial, 2 are awaiting a retrial after the jury was unable to come to a verdict, 5 pleaded guilty, 6 individuals were condemned after trial, and 6 were acquitted.

\section{The case: the first trial of a trader for the manipulation of Libor}

The case this paper builds on is the first trial of a trader accused of manipulating Libor. In December 2012, the trader Tom Hayes was 
simultaneously arrested in the United Kingdom and charged by the United States. As he stated repeatedly during the trial, he then entered a witness agreement with the Serious Fraud Office in order to preempt and avoid an extradition to the United States. After being charged in the United Kingdom, he withdrew from this agreement and decided to plead not guilty. The charges were 8 counts of "conspiracy to defraud" for the period between 2006 and 2010. During that period, Tom Hayes was an employee, first, of the Swiss bank UBS and then of the American bank Citigroup, from which he was fired in September 2010. Prior to the trial as well as after, these two banks were fined for their involvement in Libor manipulation. UBS received a fine of $\$ 700$ million from the American Commodity Futures Trading Commission [CFTC 2012], of \$500 million from the American Department of Justice [DOJ 20I2], of \$259.2 million from the British Financial Conduct Authorities [FSA 20I2], and finally of $\$ 64.3$ million from the Swiss Authority [FINMA 201 2]. Citigroup received a $\$$ I 75 million fine from the CFTC [CFTC 20I6], a $€ 70$ million fine from the European Commission [EC 20I3] and finally a CHF3,779 million fine from the Swiss Competition Commission [COMco 2016]. Hayes, a 35year-old derivatives trader, was accused of having contacted different actors in the financial industry, traders and brokers mainly, and asking them to reach submitters of the Japanese yen Libor rate in different banks. These requests were made to check the rate that the submitters were about to submit and subsequently to suggest more or less explicitly that a lower or a higher rate could benefit the positions of Hayes and the bank in the market. The fact that hundreds of such requests were made was not contested by the defendant in his defense. Many examples of these requests were presented during the trial, such as the one below, extracted from a Bloomberg chat in 2006:

- Trader (defendant): Hi T., who sets our Libors?

- Other trader: Me. Or the guy in Zurich. We use the cash to derive them...

- Trader (defendant): Ok. Could really do with six-months up, please, if possible.

- Other trader: [finishing previous sentence]... so tend to accurately reflect the movements.

— Trader (defendant): Then I needn't worry.

- Trader (defendant): ;-)

- Other trader: We have been on the high side for a while.

- Trader (defendant): Or on the fair side.

- Other trader: Fair side, exactly my thoughts. But will give it an extra notch today.

- Trader (defendant): Cheers. Most of my fixing roll off on Friday for 4 days or so. Thanks for that.

- Other trader: No problem.

Fieldwork notes, hearing no. I, 26 May 2015 
These attempts to move Libor happened not only in the banks where Hayes was an employee, but also in other banks that were part of the yen currency panel, through intermediaries such as brokers. The Financial Services Authority documented more than 800 requests overall made inside UBS [FSA 20I2], while the CFTC listed more than 2,000 [CFTC 20I2]. After Io weeks of trial, Tom Hayes was found guilty by the jury and sentenced to 14 years of jail, a sentence that was later reduced to I I years. For these reasons, through Tom Hayes's trial, the first Libor related trial to be held, the impersonal flows of finance were somehow personified by the individual sitting on trial.

\section{Data and method}

I have conducted an ethnographic investigation of this criminal trial that lasted ro weeks, and that took place in a Crown Court of London between May and August 20I5. The length of this trial of a single individual was due to its importance as the first Libor-related trial. ${ }^{5}$ During this period, I followed the hearings, paying special attention to the official presentation of financial markets by the academics who were called as witnesses, the presentation of the evidence and the way in which it was framed, the methods used to move from this single case to a larger and broader context (i.e. the financial crisis), the conflicts and controversies to emerge, the informal moments between lawyers and members of the public gallery, the imputations of responsibility, and finally the question of the interpretation and transgression of rules. This investigation also benefited from access to the official court transcripts during the 47 days of the trial, which allowed me to go back to specific hearings and consider the precise and detailed record of verbal interactions. Certain qualifications must be noted in such a focus on the trial and the use of an ethnographic methodology: what is not included in the present study is the work undertaken by lawyers and other legal professionals in preparing the trial, as well as the investigation process and the reflection on the different charges considered against the individuals involved. Nevertheless, studying a trial on financial wrongdoings is especially adapted to ethnographic methods: deviance and elite practices are the main warrants for ethnographic research [Katz I 997].

\footnotetext{
5 Indeed, six individuals faced charges in the second trial related to Libor manipula-
} 
The different elements and discussions I will expose are public testimonies made under oath, included in a legal procedure in front of a jury of $\mathbf{z} 2$ individuals and as part of the general process to either seek or avoid a conviction-a process that aims to attribute blame. Such discourses are constrained, delivered in public: while no cameras were allowed in the courtroom, press articles were published almost every day following the hearings. Such discourses may even be based on the assistance and advice of lawyers, as is frequently the case in whitecollar crime [Mann I985]. Motives indeed "stand for anticipated situational consequences of questioned conduct" [Mills i 940: 905]. From the point of view of the actors involved, the apparent truth of the justifications they provide is therefore determinant. From the point of view of a sociological analysis, the fact that the reasons given are right or wrong does not matter [Tilly 2006: 9]: it is the process of justifying and the way it is realized that is the focus of attention, as well as its social acceptability. While only the defendant was actually on trial, potentially facing a conviction, the other individuals involved, from the lawyers to the witnesses, never stopped putting boundaries between legitimate and illegitimate practices. If the process of bringing a dispute to a legal institution is a long one [Felstiner, Abel and Sarat I980-I98I], the blaming and claiming continue within the courtroom walls. This is a reason to also focus on the witnesses as they are themselves engaged in situations of justification, in blaming others, in putting boundaries between legitimate and illegitimate behaviors.

\section{Fustifications of illegalities of rights}

In order to properly analyze the justifications deployed during this trial, I will now explain the theoretical framework of this study. The principal argument is that justifications in white-collar cases, in this case financial, turn mainly around the question of rules. The historical and sociological reason for such a focus on rules has been demonstrated by Foucault: in the $18^{\text {th }}$ century, a division of the forms of illegality emerged between the illegality of property and the illegality of rights [Foucault I 977; Lascoumes I 996]. As Foucault advanced:

[T] he economy of illegalities was restructured with the development of capitalist society. The illegality of property was separated from the illegality of rights. This distinction represents a class opposition because, on the one hand, the illegality that was to be most accessible to the lower classes was that of 
property-the violent transfer of ownership-and because, on the other, the bourgeoisie was to reserve to itself the illegality of rights: the possibility of getting round its own regulations and its own laws, of ensuring for itself an immense sector of economic circulation by a skillful manipulation of gaps in the law-gaps that were foreseen by its silences, or opened up by de facto tolerance. And this great redistribution of illegalities was even to be expressed through a specialization of the legal circuits: for illegalities of property-for theft-there were the ordinary courts and punishments; for the illegalities of rights-fraud, tax evasion, irregular commercial operations-special legal institutions applied with transactions, accommodations, reduced fines, etc. The bourgeoisie reserved to itself the fruitful domain of the illegality of rights [Foucault I977: 87].

The case in this paper falls under the category of illegality of rights, in which different types of rules become entangled. During such cases, critiques of the lack of rules or the lack of their effectiveness often occupy the public debate. In the judicial processes that take place in parallel with such debate, the question of rules is also systematically raised: either the rules are denounced as not being strong enough to avoid wrongdoings, or as not being applied strictly enough. Individuals position themselves in relation to the rules, and those positions are related to specific conceptions of who is responsible, of which hierarchical relations apply, of what it is to be a good professional. Rules are considered here as playing a central role in justifications. I propose therefore to distinguish between the different characteristics of these justifications, by building on Boltanski and Thévenot [2006] as well as on Tilly [2006]. ${ }^{6}$ Three different characteristics are distinguished in that perspective and they are connected in each type of justification: a conception of rules, a narrative, and a form of responsibility.

As explained above, the first and determinant characteristic is the conception of rules. Each position of justification is here conceived as being based on a specific conception of rules, from a very strict conception to a completely lax one: the letter, the spirit or the void. The second characteristic is narrative: as Tilly argued, justifications use narrative simplification of social phenomena that allow communication. The narrative is what prevails in each justification. The third characteristic is the form of responsibility: justifications involve imputations of responsibility and aim to find identifiable individuals or entities accountable for certain actions [Tilly 2006].

\footnotetext{
${ }^{6}$ The connection between these two works has not yet been undertaken, although they have much in common. Both are dedicated to understanding the social process of justification. However, while Boltanski and Thévenot [1 999; 2006] focused on the different themes of justification and their related orders of worth,
}

Tilly [2006] differentiated justifications according to their forms. Without entering into a close discussion of each framework, which would exceed the scope of this paper, I will retain certain aspects of each in order to study the case at hand. 
T A в L E 1

Justifications about rules

\begin{tabular}{l|l|l|l}
\hline & The maker & $\begin{array}{l}\text { The } \\
\text { interpreter }\end{array}$ & The user \\
\hline $\begin{array}{l}\text { Conception } \\
\text { of rules }\end{array}$ & $\begin{array}{l}\text { Rules were } \\
\text { strict and } \\
\text { left no } \\
\text { room for } \\
\text { interpretation }\end{array}$ & $\begin{array}{l}\text { Rules were } \\
\text { relative }\end{array}$ & $\begin{array}{l}\text { Rules were } \\
\text { lax or } \\
\text { nonexistent }\end{array}$ \\
\hline Narrative & Clarity & Subjectivity & Ambiguity \\
\hline $\begin{array}{l}\text { Imputations of } \\
\text { responsibility }\end{array}$ & $\begin{array}{l}\text { Individualization } \\
\text { of responsibility }\end{array}$ & $\begin{array}{l}\text { Dilution of } \\
\text { responsibility }\end{array}$ & $\begin{array}{l}\text { Collectivization } \\
\text { of responsibility }\end{array}$ \\
\hline
\end{tabular}

These characteristics allow us to distinguish three different positions of justification that I call: the maker, the interpreter, the user. $^{7}$ Table I presents these positions and summarizes the argument of this paper, which will be empirically developed in the next section through the Libor case.

\section{Rules of justifications, justifications of rules}

I have argued so far that justifications of illegality of rights are focused on the question of rules, and that three positions of justification need to be distinguished in that regard: the maker, the interpreter and the user. What follows is an empirical demonstration of this argument through the debates heard in the first trial of the Libor scandal.

During this trial, both the defense and the prosecution focused on two questions in particular: which information should be considered legitimate for consideration when submitting the rate, and which individuals should be considered legitimate contacts when gathering

7 These positions need to be considered as ideal-types: they do not exist as such, but they help to characterize some regularity. They do not have to be considered in strict terms: an individual can try to switch from one justification to another. I assume, however, that the ability to move from one position to another is socially constrained. In order to make such a move, social actors need to argue for it and to satisfy certain requirements. However, this paper does not aim to study these displacements from one position to another. Rather, it is concerned with analyzing the characteristics of each position. 
such information. A significant rule debated during the trial was that the submission of the rate should be realized by looking at the cash market only. In an extensive consultative paper in 2008 , the BBA "emphasizes that [Libor] is a benchmark for cash and is not a derivative or FX benchmark [...]. It must be remembered that Libor is a pure cash fixing. It is not derived from derivative strip fixings or FX swap rates" [BBA 2008: I, 6]. The BBA also specified: "The rates must be submitted by members of staff at a bank with primary responsibility for management of a bank's cash, rather than a bank's derivative book." [BBA 2008: Iо]. This precision is important here, because a central aspect of the Libor scandal related to the requests made by derivatives traders to submitters of the Libor rates. ${ }^{8}$

I will empirically detail the three above-mentioned justifications towards rules, by analyzing the ways in which individuals in the trial (witnesses or defendant) justified and condemned these practices.

\section{The clarity of the maker}

The justification of the "maker" is based on clarity: the maker essentially argues that the rules were strict and explicit, expressed in a way that did not leave room for interpretation. The individuals who adopt this "maker" position are usually official representatives of the institution making the rule (such as a bank, a state institution, an association, etc.), and clearly distance themselves from any wrongdoings. They appear as a party with important legal experience-what Galanter [1 974] named repeat players.

In the Libor case, this was the role of the representatives of the British Bankers' Association and of the banks. From this position, the definition of Libor and its related rules appears to leave no room for interpretation. During the trial, the maker position was endorsed by a senior manager of Citi-former employer of the defendant-who had previously worked in the bank's treasury department for 25 years and had been the head of its European risk treasury desk since 2002. This desk was in charge of Libor submissions from 2006 to 2013 , and thus the manager "would supervise and oversee the individuals that made the actual submission". He was also a member of the Foreign

\footnotetext{
${ }^{8}$ One could argue that the rules related to Libor were not strict at all. It is not the aim of this paper to determine whether the rules were strict or not, but to render the spectrum of interpretation of the rules made during the
}

trial and explain the logic behind it. Furthermore, to argue that the rules were not strict is the position of the user in the framework previously detailed, a position mainly adopted by the trader during the trial. 
Exchange and Money Markets Committee (FX\&MMC) since 2008, the BBA's committee responsible for defining Libor and investigating potentially irregular submissions. Asked by the prosecutor to detail the conditions of Libor submissions, the manager, testifying as a witness, explained:

- Senior manager at Citi (witness): The Libor contributors, they only see their own money market activity and they don't know any positions or whether any other trading desks within Citibank would benefit from rates being higher or low. They would not have that information available and to answer the question, just to repeat, it's not appropriate for them to take it into account if they did know.

- Prosecutor: It may sound obvious, but why is it not appropriate to take it into account?

- Senior manager at Citi (witness): The Libor contribution based on the definition for the ввA is where the bank in question, so for us Citibank, thinks that other banks would lend it money. So where it would be offered money in the interbank market. So nothing other than that really.

Fieldwork notes, hearing no. 36, 23 June 2015

For the maker, the rule was clear and "nothing other than that" should be taken into account. That position was here endorsed by a representative who spoke for an institution ("for us, Citibank") and who clearly defended the stance that no interpretative leeway was possible when submitting Libor rates. The relationship between the submitter and derivatives traders is also considered through such a lens:

- Prosecutor: Then in the context of factors which should or should not be taken into account, we touched on this earlier, but a derivatives trader asking for a particular rate, is that permissible?

- Senior manager at Citi (witness): No, it's not, and they shouldn't be taken into account by the contributor.

- Prosecutor: Why not?

- Senior manager at Citi (witness): Because there's no bearing on where the contributor thinks they could borrow money from another bank in London.

- Prosecutor: Is that sort of activity encompassed within the Libor at all?

- Senior manager at Citi (witness): Not in the definition. [...] In some of the guidance, the BBA does make reference that the rate should be formed predominantly by the cash, i.e. the money market, desks. So to that respect there is some relationship there to say it should be a money market or treasury desk that deals in the money markets, not a derivative trading desk. I guess, by extension, positions of derivatives have nothing to do with how the rate should be set.

- Prosecutor: If the position in relation to derivatives is to create a market advantage for that trader or for his desk, is that permissible?

- Senior manager at Citi (witness): No, it's not.

Fieldwork notes, hearing no. 36, 23 June 2015

The manager reaffirms here as well as in other hearings, with a calm and fluid tone, that no relationship between the submitter and 
the derivatives trader was allowed, according to the BBA's definition of Libor. He maintains that the actions of his former employee, the trader here on trial, were impermissible and distances himself from his actions. Indeed, the maker's justification implies a strong condemnation of individual wrongdoings, and aims at individualizing responsibilities. From the maker's point of view, what is expected from a professional is to follow clear rules; any deviation from such behavior can only rest upon the individual's shoulders.

Yet, the justification of the maker can be difficult to adopt in situations of publicly established irregularities. Given the existence of such irregularities, it is always possible to argue that if the rules were as clear as claimed, the scandal would not have happened. However, the scandal and the irregularities are not what the individuals endorsing the maker position are focusing on. Instead, the emphasis is on pointing to the strictness of the rule: promoting a strict conception of the rule and defending the institution responsible for making it is what the position of the maker is all about.

\section{The subjectivity of the interpreter}

The justification of the interpreter is a pivotal position between the maker and the user. It therefore needs to be analyzed particularly closely. The interpreter bases his justification on subjectivity, judgment and interpretation. The interpreter undermines the rule by claiming that what counts is not only the "letter" of the rule, but also its "spirit." The individuals adopting such a position defend the need for rules but also express the necessity of a certain liberty in the conditions of their practical application. In other words, the interpreter makes room for an interpretation of the rules. The interpreter takes the stance that the rule has to be placed in a specific context, and argues that that context largely determines how the rule should be viewed-an interpretation that is close, in a certain sense, to what ethnomethodology calls indexicality [Garfinkel i967].

One witness called by the prosecution adopted the "interpreter" position many times during his testimony. This witness was the Libor manager at the time of the scandal-the individual in the British Bankers' Association whose job was to ensure that Libor remained a valid rate and that the panel banks shared a common and valid understanding of it. To do so, the Libor manager talked regularly with members of the panel banks to ensure that Libor fairly represented 
the situation of the interbank market. For these reasons, the examination of this witness was-more or less-explicitly dedicated to the question of the rule. An initial argument advanced by the witness was to place the practices covered by the rule in a specific context, here the credit crunch of 2007-2008.

- Prosecutor: The definition [of Libor] refers to what one might call a pure cash rate?

— Libor manager (witness): That's correct.

- Prosecutor: In 2007-2008, when cash was scarce, how did that affect the definition? Did that put any strain on the definition?

- Libor manager (witness): A great deal.

- Prosecutor: Just tell us how?

- Libor manager (witness): Because the definition of Libor is in the form of a question that a bank that is submitting to Libor needs to answer and that question is: "If I was to go into the interbank market and ask to borrow a sum of money in a given currency, how much would it cost me?" Now, before the credit crunch that was not a difficult question to answer because banks frequently went into the interbank borrowing markets and borrowed money, so it would be a trivial matter to set your Libor almost. You could look at the last time you did that sort of transaction and say, "Well, that's my Libor." But those transactions became fewer and fewer and at certain times there was very, very little or no activity in these markets and, yet, we were told that we had to set Libor rates. So that puts a great deal of strain on the Libor definition and the contributing banks.

Fieldwork notes, hearing no. I6, 5 June 2015

The position of the interpreter leans towards an understanding of the rule that implies interpretation. For the interpreter, the constraining force of the rule is not discarded and is even praised. However, in order to act, the rule has to be interpreted. Rather than simply repeating the rule and claiming that it covered every situation, as the maker does, the interpreter pays close attention to the specific conditions of its practical application. In the case of Libor, those conditions were the scarcity of cash in the market due to the credit crunch crisis. With regard to such conditions, the interpreter is then asked about the kind of information the submitter should consider and take into account or discard when he chooses the rate to submit.

- Prosecutor: So how might that market inform a submitter as to the rate at which to submit a particular Libor submission?

- Libor manager (witness): So cash markets involve actual movements of chunks of real cash which represents real risk, and a derivative market is usually a much more liquid market, and by that I mean there's more trading going on. So if a cash market doesn't trade for days, a derivative market might trade many times a day and if you know that your Libor rate has historically been very closely tied to the movement in a certain derivative rate, you could infer that, “Although I haven't traded cash, I know that typically it costs me 5 basis points 
to borrow cash above this particular derivative instrument" and so it would not be unreasonable to say, "I haven't traded cash. I know that typically I'm 5 basis points above this rate. Therefore, my rate for the Libor submission today is 5 basis points above where that derivative market is at I I o'clock."

- Prosecutor: So as the financial crisis took hold, did that sort of calculation, or that sort of basis for calculation become more common, as far as you could see? - Libor manager (witness): Definitely.

Fieldwork notes, hearing no. I6, 5 June 20 I 5

From the interpreter's point of view, it is possible, with regard to certain historical elements (the credit crunch crisis), to bend the rule (and to determine the level of Libor from derivatives market). Such an interpretation opens the way to a self-referential speculation in financial markets [Orléan I999], which was often observed during the subprime crisis [Orléan 20I4]. If, in that particular situation, the Libor rate is determined with reference to a derivatives market, thentaken one step further-so are the products referenced on Libor. The exchange continued and the Libor manager detailed his conception of the rule:

- Prosecutor: Therefore, that isn't exactly within the definition, is it?

- Libor manager (witness): Well, because you're being asked the rate at which you could borrow or the rate you think that you could borrow, I think that is within an interpretation of the definition of Libor.

- Prosecutor: Right.

- Libor manager (witness): Sorry, shall we say within the spirit of the definition. - Prosecutor: That's one aspect of derivatives and how one might use that in forming a view. What about a trader or a trader's desk's position, i.e., where they might want it fixed, where they might want a rate for their book?

- Libor manager (witness): That's clearly not within the spirit or the letter of the definition.

Fieldwork notes, hearing no. I6, 5 June 2015 (emphasis added)

This expression, the "spirit of the definition", which will be repeated a number of times, is not interesting only due to the way it is worded. It also shows precisely how different types of practices can be accepted or denounced, more or less officially. Not all practices are considered legitimate in regard to the rule, but a certain margin exists. This relativity of rules, which is the justification of the interpreter, is revealed here by the manager of Libor himself-the one individual dedicated to explaining to the banks how Libor worked, and to ensuring that it fairly represented the situation of the interbank market. Enlarging the rule and claiming that it has a "spirit" opens up the possibility of more practices being made legitimate. During cross-examination by the defense lawyer, this reference to the "spirit" 
was seized upon as an opportunity to expose the misunderstandings to which such a relativity of Libor definition could contribute.

- Defense lawyer: Can we touch on, please, the spirit of the definition. I just want to clarify what your position is in relation to that. You were asked on Friday [reads the previous exchange]. Who decides what is within the spirit of the definition or not?

- Libor manager (witness): That's a difficult question. Ultimately the Foreign Exchange and Money Markets Committee (FX\&MMC), as they are responsible for the maintenance of the definition.

- Defense lawyer: Where do we see-and we will look at some documentation together today - the FX\&MMC looking at the spirit of the definition?

- Libor manager (witness): Throughout the period of the financial crisis, at if not every meeting of the committee, certainly many of the meetings, that would have been the core of what they were discussing. We recognized that there were very difficult, unprecedented circumstances in the market and that the definition of Libor might have to adapt to suit that and so the definition was discussed frequently by the committee.

- Defense lawyer: Where are the boundaries for the spirit of the definition?

- Libor manager (witness): Again, that's a difficult question. You are asking me to quantify something that is a qualitative notion.

Fieldwork notes, hearing no. I7, 8 June $20{ }_{5} 5$ (emphasis added)

The rule is not something secured here: it even requires "maintenance". The Libor manager finds it harder and harder to defend such a position: drops are forming on his forehead and his tone becomes less firm. The conception of the rule as revealed here, which I describe as that of the interpreter, is not just a linguistic expression detached from any form of social constraint: it is supported by a specific organization of the financial industry. Within the BBA, the Foreign Exchange and Money Markets Committee (FX\&MMC) regrouped the representatives of the banks of the Libor panels responsible for the submission of Libor rates. Before the scandal, the FX\&MMC was responsible for the validity of the rate and was also dedicated to dealing with difficulties related to suspected fraudulent submission. However, until 201 2, the composition of the committee was not public knowledge. At the time, the BBA argued that this was necessary to protect its members from lobbying. Furthermore, the FX\&MMC published no public reports on any illegal or illegitimate practices, and none of the Libor panel banks were ever dismissed. But how can a certain conception of the rule be maintained? This committee faced a common problem within the financial industry: self-regulation. If some fraudulent statements were made, they were made by people and institutions responsible for their own regulation. To a certain extent, this tension was embodied by the witness, whose discomfort during the examination was truly palpable. If practices 
outside the rule were reported to him, they were reported by the exact same people who were in charge of the rule.

By placing a simple activity (the submission of a rate) in a specific historical context (the credit crisis), and by explaining how diverse the practices under this rule could be, taking the rule "at the letter" appears as being incompatible with the prevalent ethos at the top of the financial industry. The interpreter pictures a strongly constrained situation in which interpretation is the only way to properly act, enabling one at the same time "to have both the profits of transgression and the profits of conformity" [Bourdieu 2016: I22, my translation], and contributing to a dilution of responsibilities. Looking at some of the annual meetings where the Libor manager discussed the validity of Libor with representatives of the banks, the defense lawyer asks him about the range of practices that could be seen as legitimate in regard to the definition:

- Defense lawyer: You recognize that what is taking place [...] is contrary to the definition of Libor, or banks are submitting contrary to the definition of Libor? Do you agree?

- Libor manager (witness): They are submitting contrary to the written definition. I don't think that they are contributing against the spirit of the definition.

- Defense lawyer: Well, it comes down to boundaries. Who determines the spirit in this instance if we've abandoned the written definition?

- Libor manager (witness): We've touched on this before. I think the spirit of something is necessarily a judgment. It's not something that has a hard boundary because the definition has a hard boundary but it's very clear, I think, what the definition is trying to do, which is to...

- Defense lawyer: Whose judgment?

- Libor manager (witness): I beg your pardon?

- Defense lawyer: Whose judgment?

- Libor manager (witness): Any fair-minded person.

- Defense lawyer: Is it the submitter? Is it the FX\&MMc? Is it the bank? Is it the BBA?

- Libor manager (witness): Well, in that the FX and Money Markets Committee is the ultimate arbiter, ultimately it's them, but the definition... We were trying to be as clear as possible so that there wouldn't be a requirement for interpretation, which is why we spent so much time discussing it and adding guidance.

Fieldwork notes, hearing no. I7, 8 June 2015 (emphasis added)

What is being claimed here by the BBA's Libor manager is that a rule is nothing without an interpretation. But that claim is slightly contested here, because the same individual also tried to explain how clear the actual rule was (the position of the maker). Of course, the law-even here, in the case of an unregulated practice-is at its strongest when it is seen as formally independent of any power relations and completely free of any particular case, as if law could speak for itself. To a certain 
extent, the move between the two positions by the Libor manager-first claiming a specific interpretation of the rules (the interpreter) and then declaring that the rules are non-interpretable (the maker)—can be largely explained as a tension between an informal and an official knowledge of the rules. On the one hand, there is a reference to tacit knowledge suddenly revealed through a public discussion based on evidence, mostly private conversations, and expressed as the "spirit of the definition": the Libor manager is talking here as an individual involved in his own practices within the industry [Katz I 977]. On the other hand, by claiming that a rule is not open to any margin of interpretation, the Libor manager puts on his "official hat" and then talks with the voice of the institution, addressing the general public. This dual position, which is usually embodied by two different people-the back-stage administrator and the official representative of the institution-or is supported in different types of situations, is personified here in one individual and in one situation, creating perceptible tension in the courtroom.

This tension between how rules should oblige individuals in order for society to function normally and how, in certain situations, the same rules should be undermined is, for Boltanski [20 I ] , the mark of the relationship to rules entertained by elites. Elites claim the legitimacy of rules but, in order to act in their own professional and private contexts, elites also defend the right to interpret rules and to slightly bend them. Such interpretation is ordinarily advanced to justify actions considered at the margin of regularity, arguing that the actions are generally errors of interpretation rather than intentional faults [Lascoumes I 986; McBarnet I 99 I; Spire 2013]. Bourdieu, in his paper on codification, linked social success to the specific understanding of rules that prevail in the backgrounds of the elites: "If one had to propose a transcultural definition of excellence, I would say that it is the fact of being able to play the game up to the limits, even to the point of transgression, while managing to stay within the rules of the game” [Bourdieu i 990: 78].

The justification of the interpreter is therefore based on a specific conception of what it is to be a good professional: to be able to distinguish between the rules that should be interpreted and the ones that should be followed, and to use any available leeway to interpret rules when possible. The consequence of such a position is to contribute to a dilution of responsibilities: if every rule can be interpreted, how is any real transgression of the rules possible? 


\section{The ambiguity of the user}

After having shown how justifications about rules have been expressed by referring to their strictness and clarity (the maker), or to their interpretive and subjective character (the interpreter), I will turn to the last position taken towards rules: the user. From the user's position, the justification of financial wrongdoings is based on a contestation of the clarity of the rules: their constraining power is denied, their ambiguity is revealed, and even their existence as rules can be denounced. Therefore, the user is often perceived as a critical figure who contests rules and their grounds. This position was endorsed during the trial mainly by the defendant: the trader in this courtroom.

The justification of the user can be divided into three dimensions: the contestation of the rules, the introduction of a hierarchical component, and the collectivization of responsibility. These dimensions have been observed in other cases involving traders in recent years, for example, the Jérôme Kerviel case in France [Assouly and Blic 2013]. The first dimension of the justification of the user is to contest the existence of rules or at least their clarity.

- Defense lawyer: When you wrote those emails in 2010 [emails to his superior in Citibank after disciplinary actions against him], were you aware of the rules that you had broken?

- Trader (defendant): Well, no, because as far as I was aware there was not any rules.

- Defense lawyer: Did you think that you had done anything dishonest?

- Trader (defendant): No. I never asked for an inaccurate rate which, to my knowledge at the time was not in line with the definition. Which was, albeit cash at I I am but, yeah. [...]

- Defense lawyer: I just want to draw your attention to: "Truth to be told I am very confused as to the exact rules that I broke when I spoke to our cash desk." [abstract from an email of the defendant] Was that truthful?

- Trader (defendant): Yeah, I had no idea. Like, what, there weren't any rules. What rules have I broken and moreover this is totally consistent with other people's behavior and all my managers knew [...] I mean, prior to the rules being introduced after the investigation started there were no rules and I was never told by anyone that what I was doing was wrong, could be wrong, you know.

Fieldwork notes, hearing no. 64 , I० July 2015

Regarding the practices related to Libor and in order to explain and justify his actions, the trader is here clearly denouncing the rules. He regularly argued during the trial that his practices were not designed to get around the definition of Libor or to contribute to the submission of an "inaccurate" rate. On the contrary, he denied any dishonest practices and described the industry as one in which such practices were collectively adopted. 
The second dimension of the justification of the user is to integrate a hierarchical component: the trader emphasizes here that the bank's hierarchy were aware of his actions. The trader argues that the breaching of the rules cannot be considered without also questioning his superiors and the bank's lawyers. If the senior managers were aware of what he was doing, how could the rules have been broken? The underlying question raised by the user is: who is in charge of rules? Is it the institution responsible, the BBA, or the superiors who allowed the irregular practices to continue? ${ }^{9}$ It is worth noting that many of the traders and individuals who were charged and prosecuted came from middle-class backgrounds ${ }^{10}$, had often graduated from mid-level universities, and had rapidly advanced within their industry - that was the case of the trader here on trial ${ }^{\mathrm{II}}$. Once their actions were revealed and publicly discussed, they were usually accused of having betrayed not only the "spirit" of the rule but also its "letter", while individuals at the top of the social hierarchy argue their good faith-usually from the "maker" position.

- Trader (defendant): I didn't think it was wrong [to contact other members of the industry to move the Libor] and every lawyer of management right up to very senior managers knew everything that I did at all times. And I can't reconcile the fact that $I$ could operate in such a transparent way with all my managers and everything else and that it was wrong and, you know, even now, even now I still can't understand, you know, when you have to choose a rate and the rate is chosen every day by submitters who are also traders, submitters who have commercial interests, not any more but at the time.

Fieldwork notes, hearing no. 63 , Iо July 2015

\begin{abstract}
9 In his work on rules, Weber argued that rules should be considered by their actual uses rather than by their supposed uses [Weber 2012]. Discussing the German card game of skat, Weber said that "The 'rule of the game' - [conceived], of course, not as the 'ideal' norm of the 'laws of skat', but [as] the idea that the players in a concrete game have of its content and its binding force-is one of the motives determining the actual conduct of the players. [Each] player will-normally-'assume' that all the other [players] will make the rule of the game their 'maxim' of conduct. This assumption is in actual fact normally made (it may subsequently be verified to a greater or lesser extent) and, as a rule, it is the substantive 'precondition' of the decision by each of the players actually to let his own action be determined by the corresponding maxim-or, if he is a cheat, to pretend that it is being so determined" [Weber 2012: 213].
\end{abstract}

10 In a research project on white-collar crime started in the r99os at the University of Yale [Wheeler 1993], the argument was advanced that white-collar crime is mostly committed by middle class individuals [Weisburd et al. I99I]. Still, there is a strong difference between the individuals engaging in white-collar crime and the individuals which are convicted of whitecollar crime: one would need to be extremely cautious in drawing conclusions for the former from the latter.

I This rapid advance through the financial industry can be seen in the evolution of wages and bonuses: the trader's gross income during his time at UBS was $£ 40,726$ in 2006 ( 5 months only), and $£_{17}$ I,2 I9, £499,6I4 and $£_{409}, 82$ I respectively in 2007,2008 and 2009 ( 8 months only). During his ro months at Citigroup, his gross income was $£, 1,967,249$ in 2009 (one month only) and $\mathcal{E}_{\mathrm{I}}, 545, \mathrm{OO} \mathrm{I}$ in 2010 before being fired in September. 
The third dimension of the user's justification is the collectivization of responsibility. In order to defend himself, the trader relates his actions to a common practice within the industry. This justification allows responsibility to be de-individualized and leads to a dissemination of guilt. ${ }^{12}$ One way of doing this is to point out the conflict of interest of submitters, who can also be derivative traders at the same time. Another way of doing this is to claim that "others did the same": this expresses the view that rules were usually discarded and thus contests their importance. In the case of irregularities, responsibility lay, from the user's justification, with the institutions in charge of the rules and their application (in this case, the BBA and the banks). In other words, the user pictures himself as "more acted upon than acting" [Sykes and Matza I957]. The justification of the user is therefore usually adopted by individuals contesting their hierarchy: they point to the fact that, if the rules are relative, it is only because institutions allow them to be so.

\section{Conclusion}

This paper analyzed how members of the financial industry justify wrongdoings in relation to the rules. Based on an ethnographic investigation of the trial of a trader involved in the manipulation of Libor, I have shown how three justifications can be differentiated. Financial industry actors can claim that the rules were clear and perfectly applied (the clarity of the maker) and that only lone individuals could have transgressed them. They can also claim that the rules need interpretation in order to be used (the subjectivity of the interpreter), and that it is rather difficult to determine clear responsibility. They can finally claim that rules were inexistent or were barely conventions (the ambiguity of the user), and that everyone is in some part responsible. Each of these positions has its downsides: the maker appears as almost denying the wrongdoings involved and as

\footnotetext{
${ }^{12}$ The condemnation by the user himself of the social world he was a part of is more or less radical depending on the case. For Tom Hayes, the condemnation was partial. During the trial, the trader stated that: "I was and to a lesser degree am now still obsessed with the markets, the financial markets, and very, very, very much miss my old job and I very much
}

miss my old career. It was a big, big part of my identity, that job and that career for me." In the case of Jérôme Kerviel in France, the stigma of the $€_{4.5}$ billion loss took on a positive character. He denounced the excesses of the financial markets, in particular in his march against the "tyranny of markets" between Rome and Paris. 
fetishizing the constraining effect of rules; the interpreter has difficulty in explaining how rules can be valid and useful if everybody interprets them to their own benefit; by criticizing rules, the user appears as a figure of denunciation and as a lone individual pitted against the overall industry. These positions are not randomly adopted as we have seen in the case of the first trial concerning Libor manipulation. We can observe how, in other finance-related trials and scandals in recent years and more generally in cases of illegalities of rights, such positions were strongly related, first, to the position occupied in the financial industry and, second, to the position occupied in the blaming and accusation process.

Two main conclusions can be made regarding these justifications. First, the regularly occurring calls for a clarification of the rules often forget that it is especially difficult to get rid of subjectivity and ambiguity. The claims for a multiplication of rules also forget that in most situations it is precisely the multiplicity of rules that elites can use to their benefit. Elites usually have a privileged access to formal or informal procedures in order to deal with rules, especially in relation to corporate activity. It raises once again the question of the self-regulation of the financial industry. In the case of Libor, a major public report stated, before the Libor's administration and management was transferred to a private company (NYSE Euronext) in 2013: "while there is significant justification for regulation and reform of the benchmark, it is not clear that there is sufficient justification for a public authority to administer" [Wheatley 201 2: 22].

Second, these justifications contribute largely to the relative tolerance towards the irregularities and crimes of elites. A decade after the financial crisis and the major scandals related to activities in the banking and the financial industry, prosecutions against individuals-and moreover, against high-level executives-remain extremely rare [Pontell Black and Geis 20I4], especially compared to the more than one thousand prosecutions that took place after the savings and loan crisis of the I980s [Calavita, Pontell and Tillman I997]. As Katz argued in another historical context, "Somehow, in the very near aftermath of officially verified accounts of scandal about our elites, we are inclined to presume their legality" [Katz I980]. Rather than being perceived as deliberately illegal or fraudulent actions, as is most often the case for the irregularities of the working class, the actions of the elites appear as errors or mistakes due to a misinterpretation of the rules or a lack of clarity in the official rules [Lascoumes i 986].

I36 
Of course, this study has certain limitations, which should be considered in order to see whether the results of this case could be extended to the more general process of accusation, blame and justification that regularly emerges during financial scandals. To investigate the justifications of financial wrongdoings through the rare case of a criminal trial means that this study covers a specific scope. It therefore points to the need for further research that examines how financial actors justify their actions not only in the context of criminal law, but also in other contexts of judgment and in all the other institutions that deal with financial irregularities: "Legal punishments are to be resituated in an overall strategy of illegalities" [Foucault I 977: 272]. It does indeed appear unclearbut this will be enlightened by further investigation-how the same action can be pursued by criminal law, or by a regulatory body, or even just by internal-and informal-dispute resolution procedures [Edelman and Cahill I 998] within financial institutions.

Finally, focusing on justifications cannot allow us to fully understand and explain what leads individuals to act as they do. Yet, the justifications identified in this paper are not approached as a type of discourse appearing after the related actions: they are conceived as public and available reasons of acting which serve individuals in adopting such conduct [Mills r 940; Sykes and Matza I 957]. However, on this point, further inquiry would be required as to the common place of law [Ewick and Silbey I998] within the financial industry, and as to the way that individuals ordinary act in relation to the rules-to understand, therefore, their relationship to the rules.

\section{Acknowledgements}

Earlier versions of this paper benefited from reactions during successive presentations at the research seminar organized by Sylvain Laurens on the sociology of elites at the École des Hautes Études en Sciences Sociales, at the workshop "Genèse des futurs économiques" at the University of 'Toulouse, in Jens Beckert's research group at the Max Planck Institute for the Study of Societies, and at the 2016 conference of the Society for the Advancement of Socio-Economics at the University of Berkeley. I especially thank Marcin Serafin and Christopher Rea for their insightful comments on earlier versions of 
this paper. Finally, the investigation was realized during an academic stay at the Centre for Analysis of Risk and Regulation: I thank Andrea Mennicken for making this possible.

\section{B I B LIOGRAPHY}

Adut Ari, 2005. "A Theory of Scandal: Victorians, Homosexuality, and the Fall of Oscar Wilde", American Fournal of Sociology, I I I (I): 213-248.

Arendt Hannah, 1963. Eichmann in Ferusalem: A Report on the Banality of Evil (New York, Viking Press).

Ashton Philip and Brett Christophers, 2015. "On Arbitration, Arbitrage and Arbitrariness in Financial Markets and their Governance: Unpacking LIBOR and the LIBOR Scandal”, Economy and Society, 44 (2): I 88-2 I 7.

Assouly Judith and Damien DE Blic, 20I3. "Les traders peuvent-ils provoquer des krachs ? L'affaire Kerviel et les difficultés à imputer des responsabilités dans les crises financières”, Champ Pénal/Penal field, X.

BBA (British Bankers' Association), 2008. "Understanding the construction and operation of $\mathrm{BBA}$ LIBOR-strengthening for the future" (Retrieved from: http://www. bbatrent.com/archive/bba-announcessteps-to-strengthen-libor).

-, 2009. "BBA LIBOR: the world's most important number now tweets daily" (Retrieved from: http://www.bbatrent.com/ news-releases/bba-libor-the-worlds-mostimportant-number-now-tweets-daily).

Beckert Jens, 20i6. Imagined Futures: Fictional Expectations and Capitalist Dynamics (Cambridge, Harvard University Press).

Beckert Jens and Frank Wehinger, 20I3. "In the Shadow: Illegal Markets and Economic Sociology", Socio-Economic Review, I I (I): 5-30.

Bell Brian and John Van Reenen, 20I3. "Extreme Wage Inequality: Pay at the Very Top", American Economic Review, I03 (3): I 53-I 57.

Boltanski Luc, 20I i [2009]. On Critique: A Sociology of Emancipation (Cambridge, Polity Press).

-, 2012 [1990]. Love and Fustice as Competences (Cambridge, Polity Press).

Boltanski Luc et Elisabeth Claverie, 2007. "Le monde social en tant que scène d'un procès", in L. Boltanski, E. Claverie,
N. Offenstadt et S. Van Damme, eds., Affaires, scandales et grandes causes (Paris, Stock : 395-452).

Boltanski Luc, Elisabeth Claverie, Nicolas Offenstadt et Stéphane Van Damme, eds., 2007. Affaires, scandales et grandes causes (Paris, Stock).

Boltanski Luc and Laurent Thévenot, i 999. "The Sociology of Critical Capacity", European Fournal of Social Theory, 2 (3): 359-377.

-, 2006 [1991]. On Fustification: Economies of Worth (Princeton, Princeton University Press).

Bourdieu Pierre, I990 [1987]. In Other Words: Essays Towards a Reflexive Sociology (Stanford, Stanford University Press).

-, 2016. Sociologie Générale, Volume 2, Cours au Collège de France I983-1986 (Paris, Le Seuil).

Brickey Kathleen F., 2006. "In Enron's Wake: Corporate Executives on Trial", Fournal of Criminal Law \& Criminology, 96: 397-433.

Bryan Dick and Michael Rafferty, $20 \mathrm{I} 6$. "The Unaccountable Risks of LIBOR", The British Fournal of Sociology, 67: 7 I-96.

Calavita Kitty, Henry N. Pontell and Robert H. Tillman, 1997. Big Money Crime: Fraud and Politics in the Savings and Loan Crisis (Berkeley, University of California Press).

Carruthers Bruce, 20I5. "Financialization and the Institutional Foundations of the New Capitalism”, Socio-Economic Review, I3 (2): 379-398.

CFTC (U.S. Commodity Futures Trading Commission), i9 December 2012. "CFTC Orders UBS to Pay $\$ 700$ Million Penalty” (Retrieved from: http://www.cftc.gov/ PressRoom/PressReleases/pr6472-I2).

—, 25 May 20ı6. "CFTC Orders Citibank, N.A. and Japanese Affiliates to Pay $\$$ I 75 Million Penalty" (Retrieved from: http:// www.cftc.gov/PressRoom/PressReleases/ pr7372-I6).

Cicourel Aaron V., i995 [i968]. The Social Organization of Fuvenile Fustice (New Brunswick, Transaction Publishers). 
COMCO (Swiss Competition Commission), 2 I December 2016. "COMCO fines banks for participating in Yen LIBOR / Euroyen TIBOR cartels" (Retrieved from: https:// www.weko.admin.ch/weko/en/home/ latest-news/press-releases/nsb-news.msgid-6505 I.html).

Daston Lorraine and Peter Galison, 2007. Objectivity (New York, Zone Books).

Dobiln Frank and Dick Zorn, 2005. "Corporate Malfeasance and the Myth of Shareholder Value”, in D. E. Davis, ed., Political Power and Social Theory, vol. I 7 (Bingham, Emerald Publishing: I 79-1 98).

DOJ (Department of Justice), I9 December 2012. "UBS Securities Japan Co. Ltd. to Plead Guilty to Felony Wire Fraud for Long-running Manipulation of LIBOR Benchmark Interest Rates" (Retrieved from: https://www.justice.gov/opa/pr/ubssecurities-japan-co-ltd-plead-guiltyfelony-wire-fraud-long-runningmanipulation-libor).

EC (European Commission), 4 December 20I3. "Antitrust: Commission fines banks $€_{\mathrm{I}, 49}$ billion for participating in cartels in the interest rate derivatives industry" (Retrieved from: http://europa.eu/rapid/pressrelease_IP-I3-I 208_en.htm).

Edelman Lauren B. and Mia Cahill, i 998. "How Law Matters in Disputing and Dispute Processing (Or, the Contingency of Legal Matter in Alternative Dispute Resolution)”, in B. G. Garth and A. Sarat, eds., How Does Law Matter? (Evanston, Northwestern University Press).

Ewick Patricia and Susan S. Silbey, 1998. The Common Place of Law: Stories from Everyday Life (Chicago, University of Chicago Press).

Felstiner William L. F., Richard L. Abel and Austin Sarat, r980-r98 I. "The Emergence and Transformation of Disputes: Naming, Blaming, Claiming", Law E Society Review, I 5 (3-4): 63 I-654.

Fligstein Neil and Alexander Roehrkasse, 2016. "The Causes of Fraud in Financial Crisis of 2007 to 2009: Evidence from the Mortgage-Backed Securities Industry", American Sociological Review, 8I (4): 6I 7-643.

Foucault Michel, I977 [1975]. Discipline and Punish (New York, Pantheon).

FINMA (Swiss Financial Market Supervisory Authority), I9 December 2012. "LIBOR: FINMA concludes proceedings against UBS and orders disgorgement of profits" (Retrieved from: https://www.finma.ch/en/ news/2012/I2/mm-ubs-libor-20121219/).
FSA (Financial Services Authority), 2012. "Final Notice to UBS AG", FSA Reference number i 86,958 (Retrieved from: http:// www.fsa.gov.uk/static/pubs/final/ubs.pdf).

Galanter Marc, i 974. "Why the 'Haves' Come out Ahead: Speculations on the Limits of Legal Change", Law $\xi^{\circ}$ Society Review, 9 (I): 95-I60.

Garfinkel Harold, I967. Studies in Ethnomethodology (Englewood Cliffs, PrenticeHall).

Garrett Brandon L., 20I4. Too Big to fail: How Prosecutors Compromise with Corporations (Cambridge, The Belknap Press of Harvard University Press).

Godechot Olivier, 20I2. "Is Finance Responsible for the Rise in Wage Inequality in France?", Socio-Economic Review, Io (3): 447-470.

-, 2017 [2007]. Wages, Bonuses and Appropriation of Profit in the Financial Industry: The Working Rich (London, Routledge).

KaTZ Jack, I977. "Cover-up and Collective Integrity: On the Natural Antagonisms of Authority Internal and External to Organizations", Social Problems, 25 (I): 3-17.

—, I980. "The Social Movement Against White-Collar Crime”, in E. Bittner and S. L. Messinger, eds., Criminology Review Yearbook vol. II (Beverly Hills/London, Sage: I6I-I 82).

—, I997. "Ethnography's Warrants", Sociological Methods and Research, 25: 39I-423.

Keister Lisa A., 20I4. "The One Percent", Annual Review of Sociology, 40: 347-367.

Korom Philipp, Mark Lutter and Jens BecKERT, 2OI5. "The Enduring Importance of Family Wealth: Evidence from the Forbes 400, 1982 to 2013", MPIfG Discussion Paper, 5 (8).

KrIPPNER Greta R., 20 I I. Capitalizing on Crisis: The Political Origins of the Rise of Finance (Cambridge, Harvard University Press).

Lascoumes Pierre, 1986. Les affaires ou l'art de l'ombre. Les délinquances économiques et financières et leur contrôle (Paris, Le Centurion).

—, r996. "L'illégalisme, outil d'analyse", Sociétés Eீ Représentations, $3: 78-84$.

Lazonick William and Mary O'Sullivan, 2000. "Maximizing Shareholder Value: A New Ideology for Corporate Governance", Economy and Society, 29 (I): 13-35.

Lounsbury Michael and Paul M. Hirsch, eds., 201 о. Markets on Trial: The Economic Sociology of the U.S. Financial Crisis (Bingham, Emerald Publishing). 
MacKenzie Donald, 2007. "The Material Production of Virtuality: Innovation, Cultural Geography and Facticity in Derivatives Markets", Economy and Society, 36 (3): $355-376$

-, 2009. Material Markets: How Economic Agents Are Constructed (Oxford, Oxford University Press).

-, 20I I. "The Credit Crisis as a Problem in the Sociology of Knowledge”, American Fournal of Sociology, I I6 (6): I778- I84I.

Mann Kenneth, I985. Defending White-Collar Crime (New Haven, Yale University Press).

McBarnet Doreen, I99I. "Whiter than White Collar Crime: Tax, Fraud Insurance and the Management of Stigma", The British Fournal of Sociology, 42 (3): 323344.

Mills Charles Wright, I940. "Situated Actions and Vocabularies of Motive", American Sociological Review, 5 (6): 904-9I3.

Mollenkamp Carrick, i 6 April 2008. "Libor Fog: Bankers Cast Doubt On Key Rate Amid Crisis", Wall Street fournal (Retrieved from: http://www.wsj.com/ articles/SB I 2083 I I 64I 678 I 8299 ).

Morgan Glenn, Paul Hirsch and Sigrid QuACK, eds., 20 I 5. Elites on Trial, Research in the Sociology of Organizations, vol. 43 (Bingley, Emerald Publishing).

MüNnich Sascha, 20I5. "Thieves, Fools, Fraudsters, and Gamblers? The Ambivalence of Moral Criticism in the Credit Crunch of 2008", European Fournal of Sociology, 56 (г): 93-г I 8.

OrLÉAN André, r 999. Le pouvoir de la finance (Paris, Odile Jacob).

-, 2014 [201 I]. The Empire of Value: A New Foundation for Economics (Cambridge, MIT Press).

Philippon Thomas and Ariell Reshef, 2012. "Wages and Human Capital in the US Finance Industry, 1909-2006", Quarterly Fournal of Economics, I 27 (4): I 55I-I609.

Pontell Henry N., William K. Black and Gilbert Geis, 20I4. "Too Big to Fail, Too Powerful to Jail? On the Absence of Criminal Prosecutions after the 2008 Financial Meltdown", Crime, Law and Social Change, 6I (I): I-I3.

Porter Theodore M., I995. Trust in Numbers: The Pursuit of Objectivity in Science (Princeton, Princeton University Press).

Small Mario L., 2009. "How Many Cases Do I Need? On Science and the Logic of Case Selection in Field-Based Research", Ethnography, Iо (1): 5-38.
SPIre Alexis, 2013. "Pour une approche sociologique de la délinquance en col blanc", Champ pénal/Penal field, $\mathrm{X}$.

Sutherland Edwin H., I 983 [1949]. White Collar Crime, The Uncut Version (New Haven, Yale University Press).

Swedberg Richard, 2005. "Conflicts of Interests in the US Brokerage Industry", in K. Knorr Cetina and A. Preda, eds., The Sociology of Financial Markets (Oxford, Oxford University Press: I 87203).

Sykes Gresham M. and David Matza, 1957. "Techniques of Neutralization: A Theory of Delinquency", American Sociological Review, 22 (6): 664-67o.

TABB Rebecca and Joseph Grundfest, 2013. "Alternatives to Libor", Capital Markets Law fournal, 8: 229-260.

Thompson John B., 2000. Political Scandals: Power and Visibility in the Media Age (Cambridge, Polity Press).

Tilly Charles, 2006. Why? What Happens When People Give Reasons... And Why (Princeton, Princeton University Press).

-, 2008. Credit \& Blame (Princeton, Princeton University Press).

-, 2010. "The Blame Game", The American Sociologist, 4I (4): 382-389.

VAN DER ZWAN Natascha, 20I4. "Making Sense of Financialization”, Socio-Economic Review, I 2 (I): 99-I 29.

Volscho Thomas W. and Nathan J. Kelley, 2012. "The Rise of the Super-Rich: Power Resources, Taxes, Financial Markets, and the Dynamics of the Top I Percent, 1949 to 2008 ", American Sociological Review, 77 (5): 679-699.

Weber Max, 2012 [1907]. "R[udolf] Stammler's 'Overcoming' of the Materialist Conception of History", in H. H. Brunn and S. Whimster, eds., Max Weber: Collected Methodological Writings (London/NewYork, Routledge: 185-226).

Weisburd David, Stanton Wheeler, Elin Waring and Nancy Bode, I991. Crime of the Middle Classes: White-Collar Offenders in the Federal Courts (New-Haven, Yale University Press).

Wheatley Review, 2012. The Wheatley Review of LIBOR: Final Report (London, HM Treasury).

Wheeler Stanton, I993. "The Prospects for Large Scale Collaborative Research: Revisiting the Yale White-Collar Crime Research Program", Law and Social Inquiry, I8 (I): IOI-II3. 


\section{Résumé}

Depuis la crise financière de 2007 , l'industrie financière a été régulièrement accusée d'être trop peu regardante sur l'activité de ses membres, voire même d'encourager les pratiques délinquantes. Comment les acteurs de l'industrie financière répondent-ils à ces accusations et tentent de se défendre ? Comment justifient-ils leurs actions face aux poursuites judiciaires et à leur dénonciation publique ? Cet article répond à ces questions à partir d'une ethnographie du premier procès pénal d'un trader jugé pour la manipulation du Libor, qui s'est tenu à Londres en 2015. Le Libor est un taux d'intérêt central dans l'industrie financière, sur lequel sont indexés plus de 300 billions de dollars de contrats. L'article propose un cadre d'analyse sociologique pour saisir les justifications des illégalismes financiers et avance qu'elles sont structurées autour de trois caractéristiques : une conception des règles, un récit, une forme de responsabilité. Je distingue ainsi trois justifications, celle du créateur, de l'interprète et de l'utilisateur. Finalement, je montre comment ces justifications contribuent à la tolérance générale envers la délinquance en col blanc.

Mots-clés : Finance ; Procés ; Justifications ; Règles ; Libor ; Illégalismes de droits ; Délinquance en col blanc.

\section{Zusammenfassung}

Im Zusammenhang mit der Finanzkrise von 2007 ist die Finanzindustrie regelmäßig beschuldigt worden, den unlauteren Tätigkeiten ihrer Mitglieder wenig Beachtung zu schenken bzw. Kriminalität hervorzurufen. Wie antworten die Mitglieder der Finanzindustrie auf diese Beschuldigungen und wie versuchen sie sich zu verteidigen? Wie begründen sie ihre Handlungen gegenüber juristischen Anschuldigungen und ihrer offentlichen Verurteilung? Diese Fragen beantwortet der Aufsatz dank einer Ethnografie des ersten Strafprozesses im Libor-Skandal, bei dem 2015 ein Trader in London vor Gericht stand. Der Libor bezeichnet den Referenzzinssatz im Interbankengeschäft, der Verträge im Wert von mehr als 300 Trillionen Dollar indexiert. Der Aufsatz liefert eine soziologische Analyse, die Begründungen von Finanzunregelmässigkeiten begreifen helfen soll und verweist darauf, dass ersteren drei Charakteristika zugrunde liegen: ein Regelkonzept, eine Erzählung, eine Art der Verantwortung. Ich unterscheide zwischen drei Begründungen, jene des Schöpfers, des Interpreten und des Benutzers. Schließlich zeige ich, wie diese Begründungen zu einer allgemeinen Toleranz der White-Collar-Kriminalität beitragen.

Schlüsselwörter : Finanzwesen; Gerichte; Begründungen; Regeln; Libor; Rechtsillegalität; White-Collar-Kriminalität. 